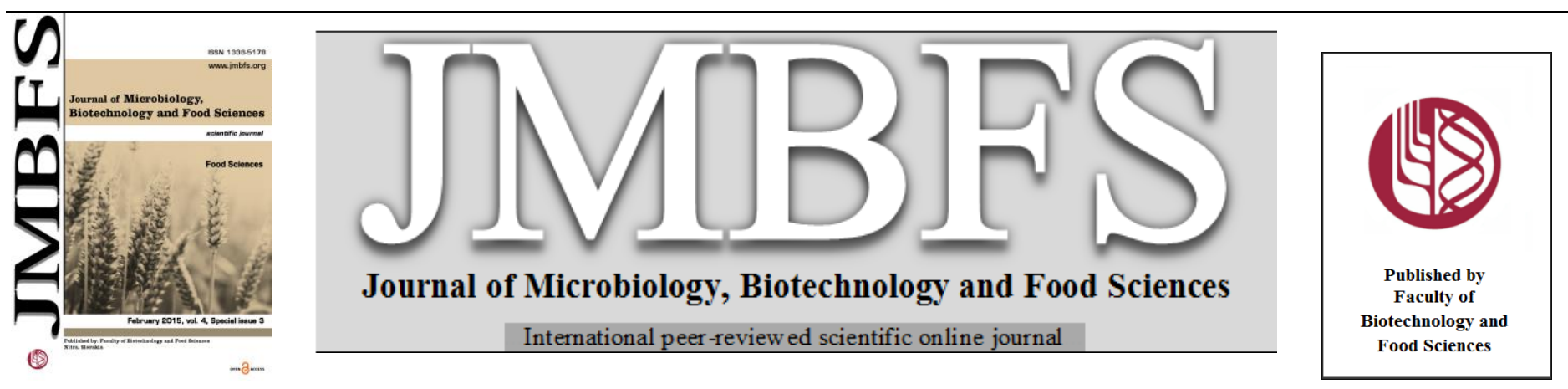

\title{
POTASSIUM AND ITS EFFECT ON THE CONTENT OF POLYPHENOLS IN ONION (ALLIUM CEPA L.)
}

\author{
Petra Kavalcová*, Judita Bystrická, Tomáš Tóth, Beáta Volnová, Miriama Kopernická, Luboš Harangozo
}

Address(es): Ing. Petra Kavalcová

Slovak University of Agriculture, Faculty of Biotechnology and Food Sciences, Department of Chemistry, Tr. A. Hlinku 2, 949 76, Slovak Republic, phone number: +421376414375 .

*Corresponding author:kavalcova.petra@gmail.com

doi: 10.15414/jmbfs.2015.4.special3.74-77

\section{ARTICLE INFO}

Received 13.11. 2014

Revised 20. 11. 2014

Accepted 21. 11. 2014

Published 2. 2. 2015

Regular article

OPEN $\bigodot_{\text {ACCESS }}$

\begin{abstract}
Onion (Allium cepa L.) is rich of chemoprotective compounds as polyphenols, flavonoids, anthocyanins, vitamins, sulphur compounds which have potential beneficial properties for human health. Potassium as important mineral abundant plays many vital roles in plant nutrition (reduces respiration, activates enzyme). In generally, potassium increases crop yield and improves quality of onion bulbs. The objectives of this work were to compare and evaluate the impact of potassium on the content of total polyphenols and antioxidant activity of onion (Allium cepa L.). The content of the total polyphenols was determined by using the Folin-Ciocalteu reagent (FCR). The absorbance was measured at $765 \mathrm{~nm}$ of wave length against blank. Antioxidant activity was measured using a compound DPPH ${ }^{\circ}(2.2-$ diphenyl-1-picrylhydrazyl) at $515.6 \mathrm{~nm}$ in the spectrophotometer. The content of total polyphenols in samples of onion during vegatation period moved in the range from $505.6 \mathrm{mg} \mathrm{GAE} / \mathrm{kg} \pm 25.18$ to $621.49 \mathrm{mgGAE} / \mathrm{kg} \pm 13.41$. In this work was watched also the influence of potassium on antioxidant activity, where values were in interval from $32.20 \% \pm 0.58$ to $44.67 \% \pm 0.68$.
\end{abstract}

Keywords: Onion (Allium cepa L.), total polyphenols, antioxidant activity, potassium

\section{INTRODUCTION}

Among all vegetables, onion is a species consumed widely across the world. Onion (Allium cepa L.) is one of the most important vegetable crops with a world production of about 55 million tonnes. Its consumption is attributed to several factors, mainly heavy promotion that links flavour and health and the popularity of onion-rich ethnic foods Dini et al., (2008). Onion (Allium cepa L.) is medica herb and belongs to the family Alliaceae. Onion (Allium cepa L.) is a rich source of flavonoids, polyphenols, organic sulphur, saponins and many other secondary metabolites which are mainly responsible for its medical activities Sohail $\boldsymbol{e t}$ al. (2011).

Onion (Allium cepa L.) is an old cultivated plant with edible bulb and has been reported for its antimicrobial, hypolipodemic, cardioprotective, antidiabetic and antioxidant activities Akerreta et al., (2007). Polyphenols represent a large class of chemical substances which are found in vegetables and fruits. Phenolic compounds are potential antioxidants and may also contribute to color, bitterness, flavor and aroma of food Joseph et al., (2005). Dietary antioxidants are important components because they protect the human body against free radicals, such as reactive oxygen species. Free radicals are known to be the major contributors to degenerative diseases of aging and are recognised as major factors causing cancer, cardiovascular disorders and diabetes Dini et al., (2008). Potassium plays a crucial role in the regulation of enzyme activities, in adjusting the electrical membrane potential and the cellular turgor, in regulating cellular homeostasis and in the stabilization of protein Sharma et al., (2013).

Potassium also plays significant roles in enhancing crop quality. High levels available $\mathrm{K}$ improve the physical quality, disease resistance and shelf life of fruits and vegetables (Cakmak, 2010). If potassium is deficient or not supplied in a dequate amounts, growth is stunted and yields are reduced. Potassium stimulates early growth, increases protein production, improves the efficiency of water use. It is vital for stand persistence, longevity,improves resistance to diseases and insects of onion (Allium cepa L.) Rehm et al., (2002).

The objectives of this work were to compare and evaluate the effect of potassium fertilizer on the content of polyphenols and antioxidant activity of onion (Allium сера L.).

\section{MATERIAL AND METHODS}

\section{Soil substrate}

In the conditions of growing pots trial were taken of soil from locality of Babindol. Babindol is located in the middle of Žitavska upland. The attitude of the village is of $205 \mathrm{~m} . \mathrm{n}$. m. Babindol belongs to the relatively warm climatic zone with average annual temperature $9.7{ }^{\circ} \mathrm{C}$ and annual rainfall $580 \mathrm{~mm}$. Babindol is locality relatively pure from point of view of content forms of risk elements (heavy metals) (Tab. 1).

Into plastic bowl - shaped pots (average of $20 \mathrm{~cm}$ and height of $25 \mathrm{~cm}$ ) was weighted six kilograms of soil from area of Babindol. Into each container were planted eight yellow onion variety of Mundo. Mundo is the world variety of onion flat- cycle and yellow gold colour. The flesh is white, firm, slightly sharper taste. These varieties are well storable with good consumer values. The average weighted of onion is $64 \mathrm{~g}$. It is grown most often from stecklings. Basic nutrient were applied in the form of aqueous solution. Potassium was applied in the form of $\mathrm{K}_{2} \mathrm{CO}_{3}$ (potassium carbonate) in two variants (Tab. 2).

\section{Sample preparation}

Samples of fresh onion we collected at the beginning, in the middle and end of vegetation period. Samples of onion were homogenized and used for prepare extract: $25 \mathrm{~g}$ of onion were extracted by $50 \mathrm{ml}$ of $80 \%$ ethanol sixteen hours. These extracts were used by analyze. The experiment was carried out in replications.

\section{Determination of total polyphenols}

Total polyphenols were determined by the method of Lachman et al., (2003) using Folin- Ciocalteau assay and expressed as $\mathrm{mg}$ gallic acid equivalent per $\mathrm{kg}$ fresh mater. The Folin- Ciocalteau phenol reagent (Merck) was added to a volumetric flask containing $100 \mu \mathrm{L}$ of onion extract. The content was mixed and $5 \mathrm{ml}$ a sodium carbonate solution (Sigma Aldrich) $(20 \%)$ was added after $3 \mathrm{~min}$. The volume was adjusted to $50 \mathrm{~mL}$ by adding of distilled water. After 2 hours, the absorbance was measured at $765 \mathrm{~nm}$ of wave lenght against blank. 
Table 1 Agrochemical characteristic of soil substrate from Babindol (mg/kg)

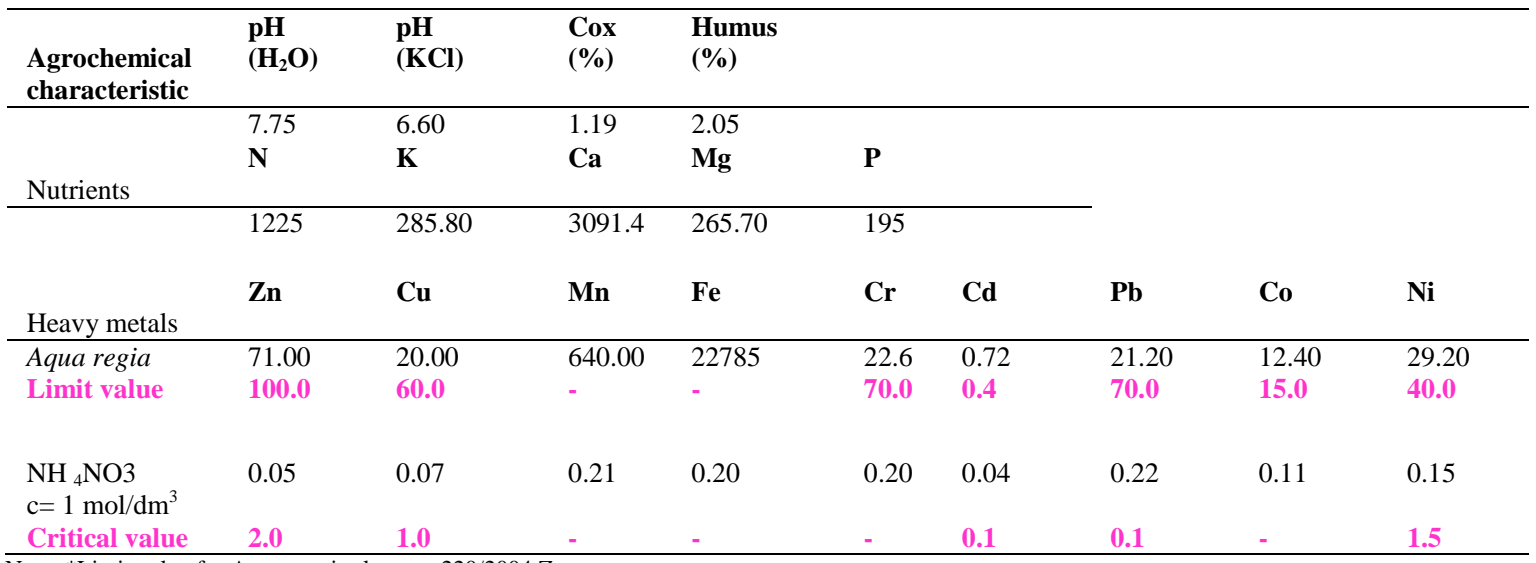

Note: *Limit value for Aqua raegia- law no. 220/2004 Z.z

**Critical value for $\mathrm{NH}_{4} \mathrm{NO}_{3}\left(\mathrm{c}=1 \mathrm{~mol} / \mathrm{dm}^{3}\right)$ - law no. $220 / 2004 \mathrm{Z} . \mathrm{z}$.

-not applicable.

Cox $(\%)$ - oxidizable carbon

\section{RESULTS AND DISCUSSION}

Table 2 Variants of pots experiments

\begin{tabular}{cc}
\hline Variant & Added amount of $\mathrm{K}(\mathrm{mg} / \mathrm{kg})$ \\
\hline Control & 0.00 \\
$\mathrm{~K} 1$ & 675 \\
$\mathrm{~K} 2$ & 900 \\
\hline
\end{tabular}

Determination of antioxidant activity

Antioxidant activity was measured by the Brand and Williams et al., (1995) method-using a radical DPPH' (2.2-diphenyl-1-pikrylhydrazyl) (Merck). 2.2diphenyl-1- pikrylhydrazyl (DPPH) was pipetted to cuvette $\left(3.9 \mathrm{~m}^{3}\right)$, then was wrote the value of absorbance, which corresponded to the initial concentration of DPPH solution in time Ao. Then $0.1 \mathrm{~cm}^{3}$ of onion extract was added. Solution in the cuvette was mixed and then was immediately started to measure the dependence $\mathrm{A}=\mathrm{f}(\mathrm{t})$. The absorbance after 1,5 and 10 minutes was measured at $515.6 \mathrm{~nm}$ in the spectrophotometer (Shimadzu UV/VIS -1240). The percentage of inhibition reflects how antioxidant compound are able to remove DPPH radical at the given time and was calculated by following formula- Inhibition $(\%)=(\mathrm{Ao}$ - At / Ao) x 100 .

Table 3 Dynamics of changes TPC (mg GAE/kg) after application potassium in onion (Allium cepa L.)

\begin{tabular}{cccc}
\hline Variant & I. sampling & II. sampling & III. sampling \\
\hline control & $508.16 \pm 27.59 \mathrm{a}$ & $615.73 \pm 20.15 \mathrm{~b}$ & $621.49 \pm 13.41 \mathrm{~b}$ \\
Added K1 & $505.38 \pm 25.18 \mathrm{a}$ & $506.45 \pm 13.82 \mathrm{a}$ & $558.05 \pm 7.83 \mathrm{a}$ \\
Added K2 & $546.45 \pm 28.93 \mathrm{a}$ & $607.99 \pm 9.54 \mathrm{~b}$ & $575.03 \pm 16.11 \mathrm{~b}$ \\
$\mathrm{HD}_{0,05}$ & 43.6439 & 23.8779 & 20.6644 \\
$\mathrm{HD}_{0,01}$ & 62.6993 & 34.3032 & 29.6938 \\
\hline
\end{tabular}

LSD Test on the significance: value $\alpha:<0.05$

Patil et al., (1995) reported that growing area and its agrochemical composition is an important environmental factor involved in the production of polyphenolic substances of onion (Allium cepa L.). Many authors found positive influence in the highest plant growth and also the highest yield and bulb quality. Delgado $e$ al., (2004) reported that the potassium fertlizers significantly increased the total polyphenols. Ruan et al., (1999) said that with the increased concentration of potassium was content of total polyphenol increased. Mudau et al., (2007) found positive correlation between potassium dose and values of total polyphenols.
Polyphenols can be divided into at least 10 different classes based upon their chemical structure, ranging from simple molecules (phenolic acids) to highly polymerized compounds (tannins). Flavonoids constitute the most important group with a common structure of diphenylpropanes (C6-C3-C6), consisting of two aromatic rings linked through three carbons that usually form an oxygenated heterocycle. Flavonoids can be subdivided into eight major subclasses, including flavonols, flavones, flavanones, isoflavones, flavanols, anthocyanins, proanthocyanidins and tannins Pietta et al., (2003).

In the work we watched the progress of making the total polyphenols content in different levels of fertilizer potassium in onion during vegetation seasons. In the experiment we determined also the influence of potassium on antioxidant activity. Nuutila et al., (2003) reported that the total polyphenol content in onion was $845 \mathrm{mg} / \mathrm{kg}$ - $2075 \mathrm{mg} / \mathrm{kg}$. Armand et al., (2012) referred that the content of polyphenols in onion was $620 \mathrm{mg} / \mathrm{kg}$. Our values of polyphenols were in the range from $505.6 \mathrm{mg} \mathrm{GAE} / \mathrm{kg} \pm 25.18$ to $621.49 \mathrm{mg} \mathrm{GAE} / \mathrm{kg} \pm 13.41$. The highes values of total polyphenols were recorded in control variant $(621.49 \mathrm{mg} \mathrm{GAE} / \mathrm{kg}$ $\pm 13.41)$ at the end of vegetation period (III. sampling). The lowest values (505.38 $\mathrm{mg} \mathrm{GAE} / \mathrm{kg} \pm 25.18$ ) of polyphenols content were determined at the beginning of vegetation period in variant I). In the case of variant $\mathrm{K} 1$ (incorporation of potassium in quantity of $675 \mathrm{mg} / \mathrm{kg} \mathrm{K}$ ) the content of polyphenols during vegetation period had high character $(505.38 \mathrm{mg} \mathrm{GAE} / \mathrm{kg} \pm 25.18-558.05 \mathrm{mg}$ $\mathrm{GAE} / \mathrm{kg} \pm 7.83$ ). In the case of variant $\mathrm{K} 2$ (incorporation of potassium in quantity of $900 \mathrm{mg} / \mathrm{kg} \mathrm{K})$ the content of total polyphenols had also high character $(546.45$ $\mathrm{mg} \mathrm{GAE} / \mathrm{kg} \pm 28.93$ - $607.99 \mathrm{mg} \mathrm{GAE} / \mathrm{kg} \pm 9.54$ ) (Tab. 3).
Between the content the potassium in the soil and total polyphenols (TPC) we have seen a slight positve correlation $(\mathrm{P}-$ value $=0,113)$ ( (Figure 1).

In this work was found weak correlation between the content of total polyphenols and the values of antioxidant activity in II. sampling $(\mathrm{P}$ - value $=0,1563)$ and III. sampling (p-value=0,2256) (Figure 2,3). 


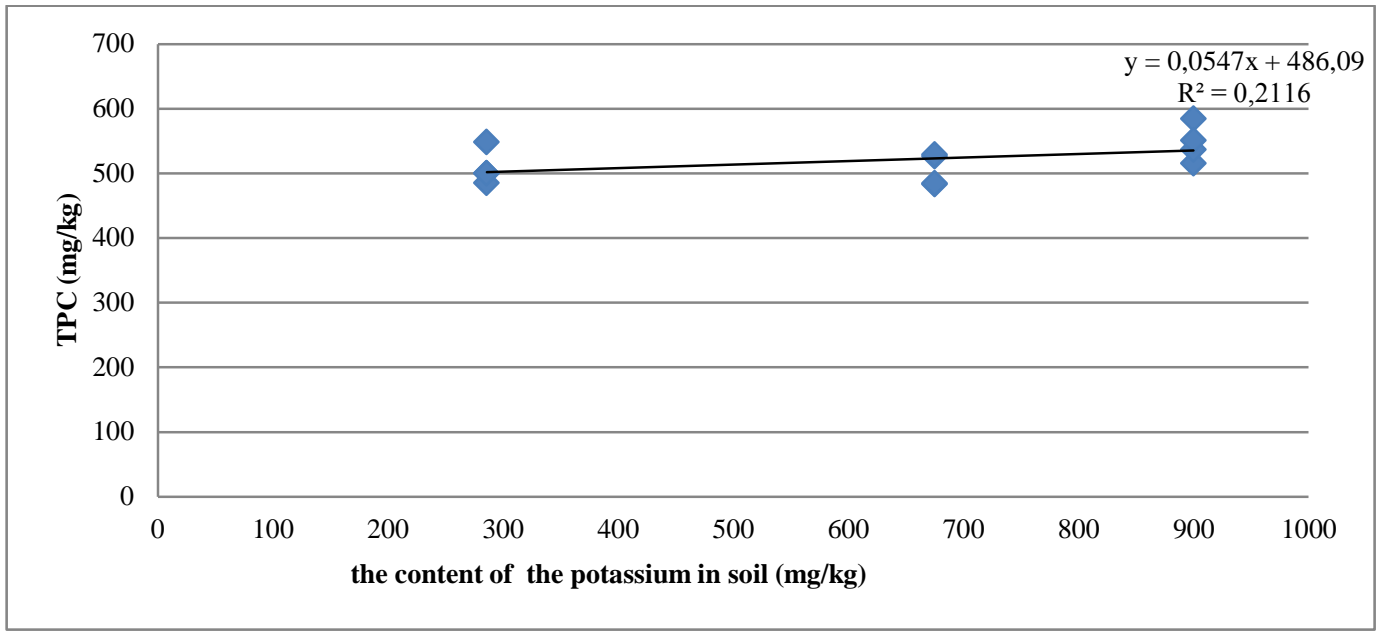

Figure 1 The dependence of the K content in the soil of the total polyphenols content (I. sampling)

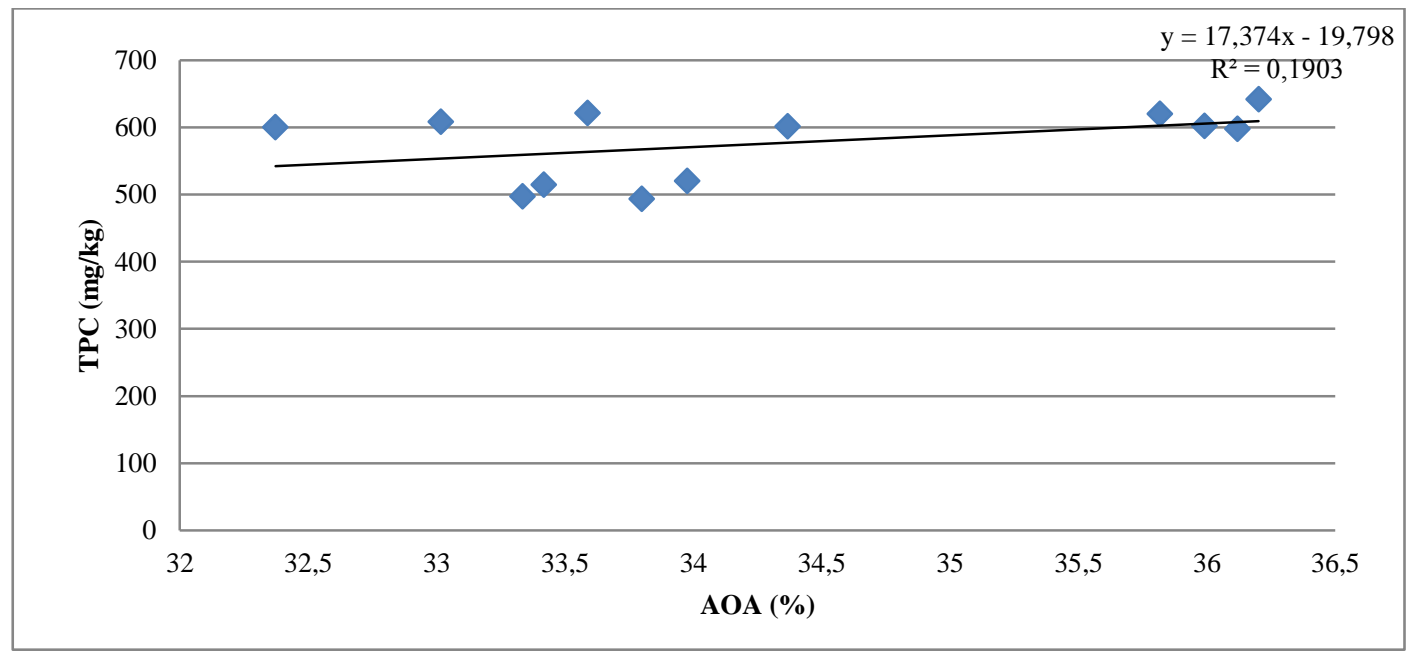

Figure 2 Relationship between the content of total polyphenols and the values of antioxidant activity (II. sampling)

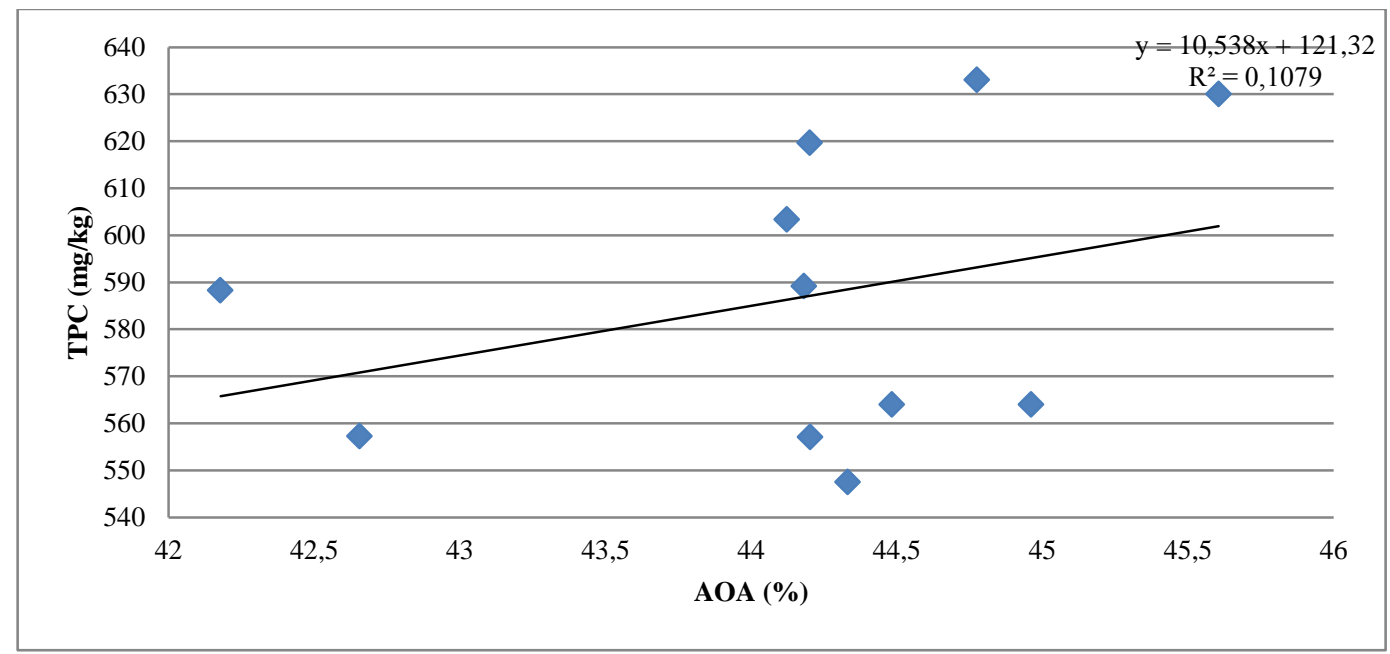

Figure 3 Relationship between the content of total polyphenols and the values of antioxidant activity (III. sampling)

Mohomed et al., (2001) reported that the content of quercetin (flavonoids) in onion was $1497.5 \mathrm{mg} / \mathrm{kg}$, kaempferol $832 \mathrm{mg} / \mathrm{kg}$ and luteolin $391 \mathrm{mg} / \mathrm{kg}$. Flavonoids are one of the major components in onion (Allium cepa L.). Manach et al., (2004) reffered that the content of quercetin in onion was in interval from $350 \mathrm{mg} / \mathrm{kg}$ to $1200 \mathrm{mg} / \mathrm{kg}$.
In this work was watched the effect of potassium on antioxidant activity. Andrejiová et al., (2011) reported that values of antioxidant activity of onion were $15-80 \%$. Our values were in interval from $32.20 \% \pm 0.58$ to 44.67 $\% \pm 0.68$ (Tab. 4). 
Table 4 Dynamics of changes AOA (\% inhibition) after application potassium in onion (Allium cepa L.)

\begin{tabular}{cccc}
\hline Variant & I. sampling & II. sampling & III. sampling \\
\hline control & $36.43 \pm 0.66 \mathrm{~b}$ & $36.03 \pm 0.16 \mathrm{c}$ & $44.67 \pm 0.68 \mathrm{c}$ \\
Added K1 & $32.20 \pm 0.58 \mathrm{a}$ & $33.63 \pm 0.30 \mathrm{~b}$ & $44.49 \pm 0.33 \mathrm{~b}$ \\
Added K2 & $33.14 \pm 0.82 \mathrm{a}$ & $33.33 \pm 0.84 \mathrm{a}$ & $42.67 \pm 0.89 \mathrm{a}$ \\
$\mathrm{HD}_{0,05}$ & 1.11864 & 0.846729 & 1.08586 \\
$\mathrm{HD}_{0,01}$ & 1.60705 & 1.21642 & 1.55996 \\
\hline
\end{tabular}

The highest values of antioxidant activity were recorded in control variant (44.67 $\% \pm 0.68)$ at the end of vegetation period (III. sampling). The lowest values $(32.20 \% \pm 0.58)$ of antioxidant activity were determined at the beginning of vegetation period in variant $\mathrm{K} 1$.

In the case of variant $\mathrm{K} 1$ values of antioxidant activity during vegetation season had high character $(32.20 \% \pm 0.58-44.49 \% \pm 0.33)$. In the case of variant $\mathrm{K} 2$ value of antioxidant activity had also high character $(33.14 \% \pm 0.82-42.67 \%$ \pm 0.89 ). Many scientific work reffered that natural polyphenols have antioxidan potencial. Polyphenols are the most abundant antioxidants in the human diet. The availability of potassium to the plant is highly variable. The molecules that signa low $\mathrm{K}^{*}$ status in plants include reactive oxygen species and phytohormones, such as auxin, ethylene and jasmonic acid. Apart from up-regulation of transport proteins and adjustment of metabolic processes, potassium deprivation triggers developmental responses in roots Ashley, et al., (2005). Potassium (K) is an essential macronutrient for plants involved in many physiological processes. It is important for crop yield and quality of edible parts of crops. Potassium deficiency affects many essential physiological and metabolic processes, determines the profile and distribution of primary metabolites in plant tissues Amtmann et al., (2012). Plants with higher levels of potassium show higher resistance to drought stress conditions. Drought stress leads to production of oxygen radicals, which results in increased lipid peroxidation (MDA biomarker) and oxidative stress in the plant Soleimanzadeh et al., (2010).

\section{CONCLUSION}

In thise work we evaluated and compared the effect of potassium in the soil on content of total polyphenols and antioxidant activity in onion (Allium cepa L.) The results suggest that increasing doses of potassium decreasing values of total polyphenols and antioxidant activity. Total polyphenols in onion may be influence by variety of onion, growing and climatic condition (altitude, annual rainfall, and annual temperature), but also the agrochemical composition of soil (humus of content, nutrients). It is know that potassium increases crop yield and quality of the bulbs onion. The results obtained in this work provide further information about the impact of potassium fertilizers of total polyphenol content and antioxidant activity of onion.

Acknowledgments: The work was supported by scientific grant VEGA 1/0290/14, VEGA 1/0456/12.

\section{REFERENCES}

AMTMANN. A., RUBIO, F. 2012. Potassium in plants. General \& Introductory Life Sciences. DOI: 10.1002/9780470015902.a0023737.

ANDREJIOVÁ, A., KÓŇA, J., BARÁTOVÁ, S. 2011. Effect of fertilization and cultivar on total polyphenol content in onion (Allium cepa L.). Nutrition and health, 12-17. [cit. 2014-09-29] http://www.slpk.sk/eldo/2012/zborniky/00512/Andrejiova_et_al.pdf.

AKERRETA, A., CAVERO, R. Y., LOPEZ, V., CALVO, M. I. 2007. Analyzing factors that influence the folk use and phytonomy of 18 medicinal plants in Navarra. Journal of Ethnobiology and Ethnomedicine, 3, 118. http://dx.doi.org/10.1186/1746-4269-3-16.

ARMAND, B. A., TOUA, V., BERNARD, G.N., NICOLAS, Y. N., DIMITRY, Y. M., MONTET, D., JOEL, S., OMF, M. 2012. Effect of solar and electric drying on the content of the phenolic compounds and antioxidant activity of three varietes of onion (Allium cepa L.). International Journal of Biology, Pharmacy and Allied Sciences, 1, 204-220. ISSN 2277-4998. [cit. 2014-09-29] http://www.researchgate.net/publication/237043783_EFFECT_OF_SOLAR_AN D_ELECTRIC DRYING_ON_THE_CONTENT_OF_THE_PHENOLIC_COM POUNDS_AND_ANTIOXIDANT_ACTIVITY_OF_THREE_VARIETIES_OF _ONION_\%28Allium_cepaL\%29.

ASHLEY, M. K., GRANT, M., GRABOV, M. 2005. Plant responses to potassium deficiencies: a role for potassium transport proteins. Journal of Experimental Botany, 57, 425-436. doi: 10.1093/jxb/erj034.

BRAND-WILLIAMS, W., CUVELIER, M. E., BERSET, C. 1995. Use of a free radical method to evaluate antioxidant activity. Lebensmittel-Wissenschaft and Technologie, 28, 25-30. http://dx.doi.org/10.1016/S0023-6438(95)80008-5.

CAKMAK, I. 2010. Potassium for better crop production and quality. Plant and soil, 335, 1-2. http://dx.doi.org/10.1007/s11104-010-0534-8.
DELGADO, R., PEDRO, M., ÁlAMO, M., GONZÁLEZ, M. R. 2004. Changes in the phenolic composition of grape berries during ripening in relation to vineyard nitrogen and potassium fertilisation rates. Journal of the Science of Food and Agriculture, 84, 623-630. http://dx.doi.org/10.1002/jsfa.1685.

DINI, I., TENORE, G.C., DINI, A. 2008. Chemical composition, nutritional value and antioxidant properties of Allium cepa L. Var. tropeana (red onion) seeds. Food chemistry, 613-621. http://dx.doi.org/10.1016/j.foodchem.2007.08.053

JOSEPH, J., SHUKITT, H. B., CASADESUS, G. 2005. Reversing the deleterious effects of aging on neuronal communications and behavior: beneficial properties of fruit polyphenolic compounds. American Journal of Clinical Nutrition, 81, 313-316. http://dx.doi.org/10.3410/f.1023511.275650.

LACHMAN, J., PRONĚK, D., HEJTMÁNKOVÁ, A., PIVEC, V., FAITOVÁ, K. 2003. Total polyphenol and main flavonoid antioxidants in different onion (Allium cepa L.) varieties. Scientia Horticulturae, 30, 142-147. Available at: http://www.agriculturejournals.cz/publicFiles/51932.pdf.

MANACH, C., SCALBERT, A., MORAND, CH. 2004. Polyphenols: food sources and bioavailability. Americal Journal Clinical Nutrition, 79, 727-747.

MOHAMED, S., MIEAN, K. H. 2001. Flavonoid (Myricetin, Quercetin, Kaempferol, Luteolin and Apigenin) Content of Edible Tropical Plants. Journal Agricultural and Food Chemistry, 49, 3106-3112. doi: 10.1021/jf000892m MUDAU, F., SOUNDY, P., TOIT, E. 2007. Effects of nitrogen, phosphorus, and potassium nutrition on total polyphenol content of bush tea (Athrixia phylicoides $\mathrm{L}$.) leaves in shaded nursery environment. Hortscience, 42, 334-338. ISSN: 0018-5345. [cit. 2014-09-29] http://repository.up.ac.za/handle/2263/5840. NUUTILA, A. M., PUUPONEN-PIRMIÄ, T., ARMI, M. 2003. Comparison of antioxidant activities of onion and garlic extracts by inhibition of lipid peroxidation and radical scavenging activity. Food Chemistry, 81, 485-493. .http://dx.doi.org/10.1016/s0308-8146(02)00476-4

PATIL, B. S., PIKE, L. M., HAMILTON, B. K. 1995. Changes in quercetin concentration in (Allium cepa L.) owing to location, growth stage and soil type. New Phytologist, 130, 349-355. http://dx.doi.org/10.1111/j.1469 8137.1995.tb01829.x.

PIETTA, P., MiNOGgIO, M., BRAMATI, L. 2003. Plant Polyphenols: Structure, Occurrence and Bioactivity. Studies in Natural Products Chemistry, 28, 257-312. doi:10.1016/S1572-5995(03)80143-6.

REHM, G., SCHMITT, M. 2002. Potassium for crop production. Nutrient managemer

2014-09-29].

http://www.extension.umn.edu/agriculture/nutrient

management/potassium/potassium-for-crop-production/.

RUAN, J., WU, X., HARDTER, R. 1999. Effects of potassium and magnesium nutrition on the quality components of different types of tea. Journal of the Science of Food and Agriculture, 79, 47 52. http://dx.doi.org/10.1002/(sici)1097-0010(199901)79:1<47::aidjsfa172>3.0.co;2-a.

MUDAU, F., SOUNDY, P., TOIT, E. 2007. Effects of nitrogen, phosphorus, and potassium nutrition on total polyphenol content of bush tea (Athrixia phylicoides L.) leaves in shaded nursery environment. Hortscience, 42, 334-338. SHARMA, T., DREYER, I., RIEDELSBERGER, J. 2013. The role of $\mathrm{K}+$ channels in uptake and redistribution of potassium in the model plant Arabidopsis thaliana Frontiers. Plant Science, 4. doi: 10.3389/fpls.2013.00224.

SOHAIL, M. N., KARIM, A., SARWAR, M., ALHASIM, M. A. 2011. Onion (Allium cepa L.). An alternate medicine for pakistani population. International $\begin{array}{llll}\text { journal of } & \text { Pharmacology, } & 7, & 736-744\end{array}$ http://dx.doi.org/10.3923/ijp.2011.736.744.

SOLEIMANZADEH, H., HABIBI, M. R., ARDAKANI, F., PAKNEJAD, F., REJALI, F. 2010. Effect of Potassium Levels on Antioxidant Enzymes and Malondialdehyde Content under Drought Stress in Sunflower (Helianthus annuus L.). American Journal of Agricultural and Biological Sciences, 5, 56-61. DOI : 10.3844 /ajabssp.2010.56.61. 